Jurnal MAKSIPRENEUR, Vol. II, No. 1, Hal 85-96

\title{
KESENJANGAN ANTARA HARAPAN DAN KENYATAAN: FENOMENA KEKECEWAAN KARYAWAN TERHADAP ORGANISASI
}

\section{Djoko Wijono}

Fakultas Ekonomi Universitas Proklamasi 45 Yogyakarta

Arundati Shinta

Fakultas Psikologi Universitas Proklamasi 45 Yogyakarta

\begin{abstract}
A tendency to compare between our output and other's output, unfortunately, is evident on nearly every employee. A source of this tendency is the psychological contract between employee and organization. Based on that psychological contract, employees often felt that they were treated unfairly by organization compared to other employees. This kind of comparison phenomenon - known as wang sinawang (Javanese) - sadly is because the employee's inability to compare objectively. This essay is addressed to discuss the psychological contract and strategy to make comparison more objectively through the equity theory. It is because almost all of employees - including ourselves - tend to compare to each other in daily activities.
\end{abstract}

Key words: Comparison, psychological contract, equity theory.

\section{PENDAhUlUan}

Karyawan adalah faktor paling penting untuk dipahami, bila organisasi menginginkan sumbangan maksimal atau bahkan luar biasa dari para karyawannya. Hal ini karena karyawan pada masa sekarang dianggap sebagai kunci utama bagi kemajuan sebuah organisasi (Rachman \& Savitri, 2012:33). Pentingnya karyawan itu dapat dilihat dari pendapat Sam Walton, salah seorang paling kaya di Amerika Serikat, dan pemilik ratusan toko Wal-Mart. Nasehatnya yang terkenal yaitu "Apabila anda bersedia memperhatikan karyawan anda dengan baik, maka mereka akan memperhatikan para pelanggan dengan baik pula, sehingga bisnis anda pun akan menjadi lancar dengan sendirinya" (If you take care of your employees, the employees will take care of your customers, and the business will take care of itself) (Bergdahl, nd.:1). 
Lancarnya bisnis organisasi menunjukkan bahwa perilaku karyawan termasuk dalam kategori good organizational citizenship. Hal itu berarti individu telah memberikan kontribusi yang semuanya bernilai positif kepada organisasi (Triyanto \& Santosa, 2009:3). Ilustrasi pada keadaan yang sebaliknya yaitu seorang karyawan yang bekerja dengan kualitas dan kuantitasyangbagus,namunia menolakuntukbekerjalemburataumenolong karyawan baru dalam melaksanakan program adaptasinya. Meskipun karyawan seperti itu prestasi kerjanya tinggi, namun ia bukan 'warga organisasi' yang baik (organizational citizenship-nya rendah). Karyawan yang lain misalnya, juga memperlihatkan prestasi kerja yang bagus. Ia juga bersedia bekerja lembur bilamana pimpinan membutuhkannya, bersedia menolong karyawan baru dalam beradaptasi dengan pekerjaannya. Ia juga dipersepsikan sebagai orang yang suka menolong dan mempunyai komitmen yang tinggi terhadap kesuksesan organisasi. Orang semacam ini disebut mempunyai organizational citizenship yang jauh lebih baik. Karyawan yang berkategori bagus sebagai warga organisasi, cenderung mempunyai kepuasan kerja yang tinggi pula.

Permasalahan yang ada, pimpinan organisasi sering kali hanya mengandalkan kontrak kerja yang tertulis, dan lupa memperhatikan karyawannya. Pimpinan organisasi sering kali kurang memperhatikan kontrak psikologi, dan sebaliknya, karyawan juga sering kecewa dengan kontrak psikologinya. Tujuan pertama tulisan ini adalah untuk menjelaskan mengapa para karyawan sering kecewa dengan organisasi tempatnya bekerja, meskipun organisasi sudah menepati segala sesuatu yang tertulis pada kontrak kerja. Apakah rasa kecewa tersebut berhubungan dengan kebiasaan wang sinawang (saling membandingkan diri sendiri dengan orang lain) (Endraswara, 2012:33; Yana, 2010:134) ketika karyawan mengevaluasi kontrak psikologinya? Tujuan kedua tulisan ini adalah membahas tentang strategi untuk mengatasi biasnya kebiasaan wang sinawang dalam dunia kerja, dengan menggunakan teori keadilan. Tulisan ini lebih ditujukan kepada karyawan bukan pimpinan organisasi, karena karyawan adalah pihak yang paling sering merasakan ketidakadilan dalam kontrak psikologi.

Pembahasan tentang kekecewaan karyawan ini penting karena hal itu bersumber dari kontrak psikologi yang dirasakan tidak adil. Rasa tidak adil ini kemudian akan menimbulkan rasa tidak puas di kalangan karyawan, sehingga karyawan cenderung mengurangi kinerjanya atau bahkan keluar dari organisasi. Tentu saja hal itu akan merugikan baik organisasi maupun karyawannya. Organisasi akan kehilangan karyawan dengan karakteristik yang sesuai dengan organisasi (karena sudah lolos dari seleksi karyawan), dan karyawan harus berburu pekerjaan lagi (hanya pada kasus yang mana angka pengangguran tinggi). 
Mengapa karyawan kecewa? Bukankah segala harapan karyawan sudah tertulis dalam kontrak kerja? Pada hampir semua organisasi yang mapan, karyawan tentu harus menandatangani surat perjanjian kerja atau lazim disebut kontrak kerja sebelum bekerja secara resmi pada suatu organisasi. Dalam kontrak kerja tersebut pada umumnya ditulis tentang deskripsi kerja karyawan, gaji dan fasilitas yang diterima karyawan, jadwal kerja, tata tertib organisasi, dan pemutusan hubungan kerja (Erna, 2010:1). Sayangnya, kontrak kerja itu tidak memfasilitasi harapan-harapan karyawan terhadap organisasi tempatnya bekerja. Harapan-harapan karyawan tersirat dalam kontrak psikologi, karena kontrak psikologi merupakan 'perjanjian tidak tertulis' antara karyawan dan organisasi.

\section{PEMBAHASAN}

Apa kontrak psikologi itu? Kontrak psikologi yaitu serangkaian harapan dan karakteristik yang dimiliki individu yang akan disumbangkan pada organisasi. Sebagai balasannya, organisasi diharapkan akan memberikan serangkaian kebutuhan kepada individu. Kontrak psikologi ini biasanya tidak tertulis, dan sering tidak secara terus terang (eksplisit) dinegosiasikan antara karyawan dan organisasi (Moorhead \& Griffin, 1995:52). Jadi kontrak psikologi ini sebenanrya menggambarkan tingkat kepercayaan (trust) dan pemahaman (understanding) menurut perasaan karyawan terhadap organisasi. Oleh karena berupa perasaan, maka kontrak psikologi ini sering tidak objektif sehingga menimbulkan masalah.

Apa saja isi dari kontrak psikologi itu? Dari pihak karyawan, karyawan 'berjanji' akan menyumbangkan segala sesuatu yang dimilikinya demi kemajuan organisasi tempatnya mengabdi. Hal tersebut antara lain meliputi kemampuan, kepercayaan, pengalaman, pengharapan, waktu, kesetiaan, ketrampilan, dan keahlian. Pihak organisasi, sebaliknya, dipersepsikan oleh karyawan 'berjanji' akan memperhatikan karyawan melalui pemberian gaji yang layak dan tepat datangnya, menjanjikan pengembangan karir, keamanan kerja, promosi, tugas-tugas yang sesuai dengan deskripsi kerja, sistem pemantauan dan evaluasi kerja yang bersiat mendidik, hirarkhi posisi, tugas-tugas dan wewenang-wewenang. Karyawan mempersepsikan bahwa kedua belah pihak akan saling memberikan segala sesuatu seperti yang telah 'dijanjikan'. Oleh karena kedua belah pihak dipersepsikan menepati 'janji' maka kontrak psikologi dirasakan menjadi adil.

Kontrak psikologi yang dirasakan adil oleh para karyawan terlihat pada hari-hari pertama bekerja. Para karyawan tentu akan bersuka cita dan bersemangat tinggi dalam melaksanakan diskripsi kerjanya seperti yang telah tertulis pada kontrak kerja. Perilaku karyawan baru pada saat-saat awal bekerja antara lain datang tepat waktu, memulai pekerjaan dengan energi baru, mencoba beradaptasi dengan lingkungan baru, mencoba berkenalan 
dengan rekan kerja baru namun tetap hati-hati dalam membawa diri, menjaga etika, tidak membanding-bandingkan dengan organisasi lama, dan terus berusaha memperbaiki diri bila melakukan kesalahan dalam bekerja (JobsDB.com, 2010:1). Usaha-usaha seperti itu menunjukkan bahwa karyawan bersemangat tinggi dan bersedia menyesuaikan diri dengan halhal baru.

Setelah beberapa saat bekerja, para karyawan mulai membandingbandingkan beberapa hal penting antara lain besarnya gaji yang diterima dengan beban kerja, interaksi sosial antara pimpinan, sesama karyawan, dan lingkungan sosial di sekeliling organisasi, dan berbagai informasi yang ada dalam organisasi. Mereka membanding-bandingkan segala sesuatu yang dimilikinya dengan karyawan lain karena hal itu merupakan bagian dari proses pengenalan budaya organisasi. Proses pengenalan budaya organisasi sering kali dilakukan melalui cerita, interaksi sosial dengan karyawan lama (Robbins, 1998:603), dan kebiasaan ngrasani (Jawa: membicarakan orang lain secara sembunyi-sembunyi) (Endraswara, 2012:33). Pada titik inilah karyawan telah berperilaku tidak adil terhadap kontrak psikologinya. Pada awal bekerja, kontrak psikologi hanya ditujukan pada dirinya saja (relasi antara diri sendiri dan organisasi), namun pada perkembangannya kontrak psikologi ditujukan pada pembandingan antara dirinya sendiri, karyawan lainnya, dan terhadap organisasi (misalnya, diri sendiri merasa organisasi lebih memperhatikan karyawan lain daripada diri sendiri). Perubahan persepsi tentang kontrak psikologi ini cenderung menimbulkan keresahan dan rasa iri hati di antara para karyawan.

Mengapa terjadi perubahan persepsi tentang kontrak psikologi yaitu dari adil menjadi tidak adil, meskipun sebenarnya tidak ada perubahan dalam kontrak kerja? Persepsi mengarahkan perilaku karyawan (Pratama, 2012:1), karena persepsi merupakan cara individu dalam memandang dan kemudian menterjemahkan lingkungan sosialnya. Jadi ketika terjadi perubahan persepsi maka terjadi pula perubahan perilaku karyawan. Perubahan itu terjadi karena perilaku individu itu sangat dipengaruhi oleh lingkungan dan situasi dalam dirinya sendiri. Pengaruh lingkungan dan situasi dalam diri individu terhadap perilaku tersebut dapat dilihat dari rumus yang dikemukakan oleh Kurt Lewin seorang tokoh yang terkenal dengan Teori Lapangan (dalam Crano \& Messé, 1982:390, Fisher, 1982:61, Thoha, 2000:11). Rumus tersebut ialah:

$$
B=f(P, E) .
$$

Rumus dari Kurt Lewin tersebut menunjukkan bahwa perilaku (Behavior) merupakan fungsi dari situasi yang ada dalam diri individu (Personal) dan situasi di luar individu (Environment). Hal itu berarti bahwa individu sebenarnya tidak otonom dalam memutuskan untuk berperilaku tertentu. Semakin kuat pengaruh lingkungan, maka perilaku individu pun semakin seragam dengan teman-temannya. Hal yang sebaliknya, semakin 
kuat pengaruh internal individu (misalnya kepercayaan diri individu sangat kuat) maka semakin berbeda perilaku individu dengan teman-temannya. Bagaimana pun, lingkungan akan terus berubah sesuai dengan kemajuan jaman. Jadi sekuat apa pun pertahanan internal individu, namun pengaruh dari lingkungan tetap harus diperhitungkan.

Individu berperilaku tertentu berdasarkan persepsinya terhadap lingkungan. Hasil persepsi itu ia olah dengan pengalaman masa lampau serta berbagai kebutuhannya. Pengalaman dan kebutuhan orang itu berbeda-beda, maka berbeda pula persepsinya terhadap lingkungan di sekitarnya. Perbedaan individu dalam mempersepsikan lingkungan ternyata juga dipengaruhi oleh kemampuannya dalam memahami obyek itu. Ini karena lingkungan menyodorkan jauh lebih banyak objek dan peristiwa untuk diamati, sedangkan manusia mempunyai keterbatasan dalam memahaminya. Dalam proses mempersepsikan lingkungan ini ternyata individu banyak mengalami distorsi atau penyimpangan. Distorsi inilah yang kadang kala sulit diramalkan, sehingga perilaku individu sering sulit untuk dipahami.

Individu berperilaku tertentu karena berdasarkan sikap senang atau tidak senang (affective). Dalam menanggapi lingkungan sekitar, tentulah individu membuat evaluasi. Evaluasi ini sering didasarkan pada perasaan senang atau tidak senang terhadap hasil perbandingannya dengan orang lain dalam kontrak psikologi. Bilamana hasil yang diterima individu dipersepsikan lebih kecil daripada hasil orang lain (target pembanding), maka ia merasa tidak puas atau tidak senang. Salah persepsi ini terjadi karena individu itu sendiri yang kurang informasi, sehingga objek perbandingan sebenarnya menjadi tidak tepat. Salah persepsi inilah yang sering merepotkan pimpinan organisasi dalam mendistribusikan imbalan (reward) pada karyawannya.

Perubahan lingkungan dalam mempengaruhi perilaku dapat terjadi antara lain melalui perubahan sistem kerja. Pada waktu permulaan bekerja, individu mungkin merasa pekerjaan itu sangat menarik dan menantang. Beberapa tahun kemudian ia berpendapat behwa pekerjaan tersebut monotoon sifatnya dan membosankan. Organisasi pun dapat mengalami perubahan drastis. Sebagai contoh yaitu ketika organisasi menggunakan sistem teknologi atau mesin-mesin yang baru. Perubahan itu mengharuskan adanya persyaratan ketrampilan yang tinggi dari karyawannya. Para karyawan terpaksa harus menambah ketrampilannya. Kalau tidak mau, maka ia akan tersisih, sehingga kontrak psikologi-nya akan semakin terasa tidak adil (Moorhead \& Griffin, 1995:52).

Hal yang menarik dari proses pembandingan ini adalah sifatnya yang sering kali tidak objektif. Dampaknya adalah munculnya rasa cemburu dan adanya prasangka bahwa organisasi lebih memprioritaskan karyawan-karyawan tertentu. Karyawan akan mengevaluasi kembali 
kontrak psikologinya. Ada kecenderungan, karyawan akan merasa tidak puas ketika kontrak psikologi dipersepsikan jauh di bawah harapannya. Mereka mungkin akan berpikir untuk keluar dari organisasi. Ketidakadilan kontrak psikologi juga bisa terjadi secara positif yaitu bila kontrak psikologi melebihi harapan karyawan. Pada kasus semacam itu, mungkin tidak ada karyawan yang akan protes. Pada tulisan ini, persepsi tentang ketidakadilan lebih ditekankan yang bersifat negatif (kontrak psikologi di bawah harapan karyawan).

Bagaimana cara menjelaskan tentang kontrak psikologi yang dirasakan karyawan tidak adil? Perasaan tidak adil tentang karyawan akan muncul ketika ia hanya membandingkan segala sesuatu yang diperolehnya dengan perolehan karyawan lain. Perasaan tidak adil tersebut sangat sesuai dengan ungkapan Jawa yaitu wang sinawang, yang berarti bahwa individu selalu melihat orang lain lebih lebih beruntung daripada dirinya sendiri (Widi, 2009:1). Tentu saja, kebiasaan membanding-bandingkan itu cenderung tidak objektif, karena topik yang dibandingkan hanya hasilnya (output) sedangkan sumbangan (input) tidak diperhatikan. Agar lebih objektif, maka teori keadilan (eguity theory) yang dikemukakan oleh J. Stacy Adams (dalam Robbins, 1998:182) memberikan strategi membandingkan diri sendiri dengan orang lain.

Teori keadilan ini menjelaskan bahwa karyawan akan selalu membanding-bandingkan antara sumbangan untuk pekerjaannya (input) dan juga hasil yang diperolehnya (ouput) dengan input dan ouput orang lain. Bila hasil perbandingan itu ternyata individu merasakan ada ketidakadilan, maka individu akan berusaha agar terjadi keadilan lagi. Penjelasan tentang perbandingan itu akan lebih mudah dipahami dengan tabel di bawah ini:

Tabel 1.

Rasio perbandingan dan persepsi yang muncul pada teori keadilan

\begin{tabular}{|l|l|}
\hline Rasio Perbandingan & \multicolumn{1}{c|}{ Persepsi yang Muncul } \\
\hline O / I A < O / I B & $\begin{array}{l}\text { Tak adil, imbalan terasa lebih sedikit } \\
\text { (lessrewarded). Individu merasa menjadi seperti } \\
\text { anak tiri. }\end{array}$ \\
\hline O / I A = O / I B & Adil \\
\hline O / I A > O / I B & $\begin{array}{l}\text { Tak adil, imbalan terasa lebih banyak } \\
\text { (overrewarded). Individu merasa menjadi seperti } \\
\text { anak emas. }\end{array}$ \\
\hline
\end{tabular}

Catatan: O adalah output, I adalah input, A adalah karyawan itu sendiri, dan B adalah karyawan lain. Contoh output yaitu gaji dan input adalah tingkat pendidikan (Robbins, 1998:183). 
Tabel itu menunjukkan bahwa bila hasil yang diperoleh dengan sumbangan (input) tertentu itu ternyata lebih kecil daripada orang lain, maka individu akan merasa diperlakukan tidak adil. Perasaan tidak adil juga terjadi ketika hasil yang diperoleh itu ternyata lebih besar daripada orang lain. Individu merasa diperlakukan dengan adil oleh organisasi bila hasil perbandingan itu sama dengan orang lain. Jadi, apabila karyawan ingin membandingkan dirinya dengan rekan kerjanya maka yang harus dibandingkan tidak hanya hasil akhirnya saja (misalnya gaji, penghargaan dan keistimewaan-keistimewaan yang diterima karyawan dari organisasi), tetapi juga jumlah dan kualitas sumbangannya terhadap organisasi (misalnya kerja keras, pengorbanan, kepedulian terhadap organisasi).

Tabel di atas sebenarnya juga dapat berguna untuk menterjemahkan pikiran para karyawan yang merasa kontrak psikologinya tidak adil. Berdasarkan tabel tersebut, ada beberapa kemungkinan perilaku yang akan dimunculkan apabila karyawan merasa kontrak psikologinya tidak adil (Walster, Walster, \& Scott, 1989 dalam Robbins, 1998:183), meskipun organisasi sudah memenuhi segala sesuatu yang tercantum dalam kontrak kerja tertulis. Harapan karyawan, perilaku-perilaku ini dapat membuat kontrak psikologi menjadi lebih adil.

1. Karyawanakanmengubahinputatau sumbangannya terhadaporganisasi. Contoh perilaku yaitu meninggalkan pekerjaan untuk sementara waktu (absenteeism) berdasarkan alasan pura-pura sakit (feigned). Dampak perilaku ini ialah terbengkalainya pekerjaan organisasi, kualitas dan kuantitas tugas organisasi menurun.

2. Karyawan itu akan mengubah output atau hasil produksinya. Contoh perilaku adalah pada karyawan yang digaji berdasarkan jumlah barang yang dihasilkannya. Ia kemudian akan bekerja keras untuk menghasilkan barang dalam jumlah yang banyak tetapi kualitasnya rendah.

3. Menyimpangkan persepsi tentang dirinya sendiri. Contohnya, karyawan semula menganggap dirinya telah bekerja pada tingkat moderat atau biasa-biasa saja. Anggapan itu kemudian disimpangkannya menjadi anggapan bahwa ia telah bekerja terlampau keras. Berdasarkan anggapan ini, maka karyawan merasa 'sah' untuk mengendurkan kinerjanya demi mendapatkan kontrak psikologi yang lebih adil.

4. Menyimpangkan persepsi tentang orang lain. Contohnya, karyawan menganggap bahwa pekerjaan saingannya itu tidak semenarik seperti yang semula diduganya. Karyawan kemudian beranggapan bahwa tugasnya sendiri lebih menarik daripada tugas saingannya, sehingga kontrak psikologi dirasakan emnjaid lebih adil.

5. Mengganti orang yang dijadikan pembanding. Contohnya, seorang karyawan mengatakan bahwa prestasinya memang tidak setinggi saudara iparnya namun paling tidak prestasinya jauh lebih tinggi daripada bapaknya ketika bapaknya itu seusia dia. Semula pembandingnya adalah saudara iparnya sendiri, kini pembandingnya adalah bapaknya sendiri. 
6. Keluar dari arena kompetisi, yaitu keluar dari pekerjaan (turnover). Turnover ini menyebabkan organisasi mengalami kerugian karena harus mengganti posisi yang kosong tersebut. Bila karyawan yang keluar itu kualitasnya tinggi, maka kerugian organisasi menjadi berlipat karena organisasi harus mendidik karyawan baru. Salah satu cara organisasi untuk mengatasi turnover yaitu mempersilakan karyawan untuk mengundurkan diri, daripada organisasi memecat karyawan. Bilamana karyawan yang memilih mengundurkan diri itu adalah yang prestasi kerjanya rendah atau yang paling memperlihatkan rasa tak puas terhadap pekerjaan, maka organisasi justru memetik keuntungan dari peristiwa turnover ini.

Kontrak psikologi yang dirasakan tidak adil oleh karyawan sebenarnya juga berasal dari tidak tepatnya target pembanding. Pertanyaan yang relevan adalah apakah bisa pembandingan dilakukan terhadap setiap teman kerja yang lebih berhasil hidupnya (orang yang output-nya lebih besar daripada output diri sendiri). Pertanyaan semacam itu penting karena dalam kehidupan sehari-hari, hampir setiap orang tentu mengalami rasa iri hati terhadap keberhasilan orang lain. Persoalannya adalah target pembandingan itu sering kali keliru. Sebagai contoh, Anda sekarang ini berumur 40 tahun dan merasa iri hati kepada rekan kerja yang umurnya separuh Anda. Tentu saja hal ini tidak sebanding. Jadi siapa saja yang sebaiknya dijadikan pembanding? Goodman pada tahun 1974 dan peneliti lainnya (dalam Robbins, 1998:183) menunjukkan bahwa ada empat target pembanding yang lebih objektif yaitu:

1. Self-inside, artinya individu membandingkan dengan pengalaman dirinya sendiri pada posisi pekerjaan yang berbeda pada organisasi tempatnya sekarang bekerja.

2. Self-outside, artinya individu membandingkan dengan pengalamannya sendiri ketika ia bekerja di organisasi yang berbeda dengan organisasi tempat kerjanya sekarang ini.

3. Other-inside, artinya individu membandingkan dengan orang lain atau sekelompok orang yang juga bekerja pada organisasi yang sama.

4. Other-outside, artinya individu membandingkan dengan orang lain atau sekelompok orang yang bekerja di luar organisasi tempat individu sekarang ini berkarya.

Jadi target pembanding itu bisa berupa dirinya sendiri atau orang lain, baik dari dalam maupun luar organisasi tempatnya sekarang ini bekerja. Ketepatan individu dalam mencari pembanding itu sangat bergantung pada informasi yang diperolehnya tentang kondisi pembanding dan juga kemenarikan pembanding itu. Semakin sedikit informasi yang diperolehnya, maka semakin tidak akurat pembandingnya. Semakin menarik target pembanding itu, semakin individu itu ingin membandingkannya meskipun informasi yang diperolehnya tentang target tersebut hanya minim saja. Jadi dalam hal ini dapat dipahami bila kontrak psikologi sangat rawan untuk 
menjadi tidak adil karena subjektivitas yang tinggi pada para karyawan tersebut. Apalagi bila tingkat pengangguran tinggi, sehingga karyawan akan lebih memilih bertahan dalam organisasi meskipun mereka merasa sangat tidak puas.

Strategi berikutnya yang berguna untuk mengurangi subjektivitas proses pembandingan diri sendiri dengan rekan kerja dalam kontrak psikologi adalah dengan mempertimbangkan karakteristik demografi target pembanding. Karatersitik demografi tersebut meliputi gender, lama kerja, tingkatan posisi dalam organisasi, dan tingkat pendidikan yang ditempuh atau tingkat profesionalisme (Kulik \& Ambrose, 1992 dalam Robbins, 1998:12). Karakterisitk demografi tersebut berperan sebagai variabel antara.

Untuk variabel gender, ternyata orang-orang lebih memilih pembanding yang sama gendernya. Hal itu berarti laki-laki lebih memilih laki-laki sebagai pembandingnya, begitu juga dengan perempuan lebih memilih perempuan. Pembandingan ini dilakukan untuk mengatasi pesepsi yang muncul bahwa gaji pada karir maskulin lebih tinggi daripada karir feminin (Mather, 1985:153). Selain itu, pembandingan juga dilakukan untuk mengatasi ketidakadilan yang terjadi dalam hal penerimaan gaji antara karyawan perempuan dan laki meskipun posisi pekerjaannya sama. Di Bangladesh, sebagai salah satu contoh budaya patriakat (mengagungkan laki-laki), para guru perempuan sekolah negeri merasa kurang puas dengan pekerjaannya dibandingkan guru laki-laki dalam hal hal gaji, kekuasaan, proposi, dan lingkungan sosial (keharmonisan relasi dengan teman kerja) (Tasnim, 2006:87). Kepuasan kerja 125 karyawan bank di Nigeria juga lebih rendah daripada kepuasan kerja 215 karyawan laki-laki. Padahal semua karyawan bank yang diteliti tersebut mempunyai karakterisitk yang hampir sama seperti usia 30-40 tahun, tingkat pendidikannya sarjana, posisi pekerjaan (supervisor, manager tingkat menengah, dan manager senior), dan pengalaman kerja (Okpara, 2004:90).

Apa saja dampak pembandingan yang sama gender ini? Perempuan lebih suka membandingkan dirinya dengan perempuan juga, sehingga harapan perempuan mengenai tingkatan gajinya menjadi lebih rendah daripada laki-laki pada posisi pekerjaan yang sama. Dengan perkataan lain, perempuan tidak merasa risau ketika mendapatkan gaji lebih rendah daripada karyawan laki-laki pada posisi yang sama. Hal ini karena ukuran baku yang ditetapkan karyawan perempuan itu memang lebih rendah daripada ukuran baku untuk karyawan laki-laki. Hal yang menarik adalah pada pekerjaan yang pada umumnya tidak dihubungkan dengan gender (not gender segregated job) maka karyawannya cenderung memilih pembanding tidak berdasarkan gender, tetapi pada variabel lainnya seperti lama kerja, pendidikan, dan sebagainya. Jadi mungkin saja karyawan lakilaki membandingkan dirinya dengan karyawan perempuan, atau sebaliknya. Untuk pekerjaan yang secara stereotip ada hubungannya dengan gender 
(seperti sekretaris biasanya untuk perempuan), maka karyawan sering melakukan pembandingan dengan rekan kerja sama gender.

Variabel selanjutnya yang hendaknya dipertimbangkan dalam membanding-bandingkan diri sendiri dengan orang lain dalam kontrak psikologi adalah lama kerja. Karyawan yang baru saja diterima pada suatu organisasi (tingkatnya rendah pada variabel lama kerja) tentu saja hanya mempunyai sedikit informasi tentang teman-teman sekerjanya. Informasi yang dimilikinya pun belum tentu akurat, karena ia adalah orang baru yang belum mengenal temannya secara lebih mendalam. Oleh karena itu pembandingnya biasanya adalah dirinya sendiri. Karyawan yang telah lama bekerja pada suatu organisasi, sebaliknya, cenderung menganggap teman sekerjanya sebagai pembanding. Hal ini karena teman sekerja dipersepsikan mempunyai pengalaman dan lama kerja yang hampir sama, sehingga diperkirakan sepadan untuk dijadikan pembanding.

Tingkat profesionalisme adalah variabel selanjutnya yang penting untuk dipertimbangkan dalam memilih target pembanding. Karyawan yang sduah sangat profesional, berpendidikan tinggi, dan posisinya kuat dalam suatu organisasi, cenderung memilih orang yang berada di luar organisasi (otheroutside). Hal ini karena karyawan yang mempunyai karakteristik seperti itu mempunyai informasi yang luas. Bahkan tidak jarang, target pembanding itu adalah orang-orang yang berada di negara lain atau pembandingan lintas negara.

Perasaan seperti'anak tiri' atau tidak diperhatikan oleh organisasi tempat seseorang bekerja tentu akan menyebabkan kontrak psikologi menjadi tidak adil. Idealnya, memang pihak organisasi dan pihak karyawan sendiri hendaknya perlu duduk bersama dan saling menkomunikasikan segala sesuatu yang tidak sesuai dengan harapan kedua belah pihak. Hal itu biasa dilakukan misalnya dalam pertemuan rutin evaluasi kinerja. Dari pihak organisasi, hendaknya para pimpinan organisasi juga menerapkan prinsip seperti yang dikemukakan oleh Sam Walton bahwa karyawan adalah kunci keberhasilan organisasi (Moorhead \& Griffin, 1995:8). Kepedulian pimpinan pada karyawan menandakan bahwa organisasi tidak merasa semenamena bahwa organisasi dibutuhkan oleh karyawan. Hal ini seperti ajaran Jawa yaitu aja dumeh atau merasa dirinya lebih daripada pihak lainnya (Endraswara, 2012:173, Yana, 2010:86).

Pada sisi karyawan, hendaknya juga diminta untuk waspada terhadap perubahan yang terjadi pada lingkungannya. Kewaspadaan ini akan berdampak pada kesediaannya untuk mengubah diri terhadap perubahanperubahan yang terjadi pada organisasi tempatnya berubah. Karyawan menjadi lebih tanggap, sehingga ia menjadi lebih luwes dalam menghadapi kontrak psikologi yang mungkin saja dianggapnya tidak adil. Selain itu, mengubah kebiasaan karyawan untuk membanding-bandingkan dirinya dengan orang lain memang tidak mudah. Pembandingan dengan orang 
lain hendaknya dilakukan secara ngukur sarira (Yana, 2010), yang berarti kelebihan orang lain hendaknya dilihat sisi positifnya yaitu sebagai sumber motivasi untuk lebih maju (Robbins, 1998:185; Yana, 2010:134). Kelebihan orang lain bukan sebagai sumber keirian yang dapat memecah belah ketentraman bekerja di organisasi, tetapi justru sebagai sumber untuk saling mendorong demi kemajuan organisasi.

\section{KESIMPULAN}

Mencapai kontrak psikologi yang adil memang tidak mudah. Hal ini karena orang sering kali keliru dalam memahami kontrak psikologi. Sebenarnya sumber dari keresahan tentang tidak adilnya kontrak psikologi adalah karena kebiasaan wang sinawang (Widi, 2009:1), sehingga individu selalu merasa orang lain selalu lebih sukses daripada dirinya. Seandainya individu mampu memahami dan melaksanakan konsep Jawa seperti nrimo ing pandum (menerima dengan hati besar mengenai segala sesuatu yang menimpanya) tentu ia akan merasakan kontrak psikologinya adil. Konsep menerima segala sesuatu yang menimpanya yang bernilai baik atau buruk, tidak berarti individu menjadi pasif. Justru karena individu mampu menerima konsep tersebut maka ia dapat memahami bahwa ada sesuatu yang kurang pada dirinya dibanding orang lain. Kekurangan itu merupakan landasannya untuk bangkit (Thohir, Inrahti, \& Purnomo, 1994:4).

\section{DAFTAR PUSTAKA}

Bergdahl, Michael, n.d., Questions and Answers About Sam Walton and WalMart, diakses pada 14 Desember 2012 dari: http://www.michaelbergdahl. net/qanda.shtml

Crano, William. D. dan Lawrence A. Messé, 1982, Social Psychology: Principles and Themes of Interpersonal Behavior. Homewood, Illinois: Dorsey Press.

Endraswara, Suwardi, 2012, Falsafah Hidup Jawa. Cetakan ke-5. Yogyakarta: Cakrawala.

Erna DK., 2010, “Apa Saja Isi Wajib Kontrak Kerja”, dimuat dalam Majalah Chic. 25 November 2010. Diakses pada 17 Desember 2012 dari: http:// female.kompas.com/read/2010/11/25/12080761/apa.saja.isi.wajib. kontrak.kerja

Fisher, Ronald. J., 1982, Social Psychology: An Applied Approach. New York: St. Martin Press.

JobsDB.com, 2010, Tips Hari Pertama Kerja di Tempat Baru. Diakses pada 18 Desember 2012 dari http://id.jobsdb.com/ID/ID/Resources/ JobSeekerArticle/Tips\%20Hari\%20Pertama\%20Kerja?ID=400

Mather, C., 1985, “Rather Than Make Trouble, It's Better Just to Leave Behind the Lack of Industrial Strife in the Tangerang Region of West Java". 
Dalam H. Afshar (Ed.). Women, Work, and Ideology in the Third World. (pp. 153-180). London: Tavistock Publications.

Moorhead, Gregory dan Ricky W. Griffin, 1995. Organizational Behavior: Managing People and Organizations. Boston: Houghton Mufflin Company.

Okpara, John O., 2004, “The Impact of Salary Differential on Managerial Job Satisfaction: A study of the Gender Gap and Its Implications for Management Education and Practice in a Developing Economy", The Journal of Business in Developing Nations. 8, 65-92.

Pratama, Nugraha Adhya, 2012, Persepsi Menentukan Perilaku. Diakses pada 20 Desember 2012 dari: http://pratama-khatulistiwa.blogspot. com/2012/01/persepsi-menentukan-perilaku.html

Rachman, Eileen \& Sylvina Savitri, 2012. "Are you a people person?", dimuat dalam Kompas Klasika, 22 Desember 2012, halaman 33.

Tasnim, Shamima, 2006, "Job Satisfaction Among Female Teachers: A Study on Primary Schools in Bangladesh. Thesis submitted in partial fulfilment of the M. Phil. Degree Department of Administration and Organization Theory, University of Bergen, Norway. Diakses pada 23 Januari 2012 dari https:// bora.uib.no/bitstram/1956/1474/1/Masteroppgave-tasnim.pdf

Thoha, Miftah, 2000, Perilaku Organisasi: Konsep Dasar dan Aplikasinya. Cetakan ke-11. Jakarta: PT Raja Grafindo Persada.

Thohir, Mudjahirin, Sri Inrahti, dan Mulyo Hadi Purnomo, 1994, "Makna Miskin Bagi Keluarga Miskin: Kasus Buruh Ukir di Jepara". Laporan Penelitian. Pusat Penelitian Sosial Budaya, Lembaga Penelitian Univesitas Diponegoro, Semarang.

Triyanto, Agus \& The Elisabeth Cinty Santosa, 2009, "Organizational Citizenship Behavior (OCB) dan Pengaruhnya Terhadap Keinginan Keluar dan Kepuasan Kerja Karyawan". Jurnal Manajemen. 7 (4), 1-13.

Widi, Wahyuning, 2009, Wang Sinawang, diakses pada 23 Desember 2012 dari http://jalmajawa.blogspot.com/2009/12/kanggone-wong-jawatembung-wang.html

\section{Ucapan terima kasih:}

Penulis mengucapkan terima kasih kepada Prof. Dawam Rahardjo, Rektor Universitas Proklamasi 45 Yogyakarta, yang sudah memberi komentar pada versi pertama tulisan ini. 